\title{
DEVELOPMENT OF METHODS FOR REMOTE MONITORING OF ALLOCATION OF LOCAL AREAS OF OPPRESSED VEGETATION ON CULTIVATED PASTURE UNDER INFLUENCE OF VARIOUS NEGATIVE FACTORS
}

\author{
Vladimir Trukhachev, Serhii Oliinyk, Tatyana Lesnyak, Vitaly Morozov, Sergey Sklyarov \\ Stavropol State Agrarian University, Russia \\ inf@stgau.ru, soliynik60@gmail.com, tatastav026@gmail.com, ssklyar@mail.ru
}

\begin{abstract}
The development of the methods for assessing local areas of oppressed vegetation is shown. The field contours were refined according to the Earth remote sensing data (panchromatic, color and multispectral images of the earth's surface) using the complex of automatic decoding and vectorizing. After processing and evaluating the results, the raster orthomosaic is transformed into a set of vector linear objects, known as field contours. In addition to topographic interpretation, a multispectral classification is performed. For these purposes, statistical and textural characteristics were used on any raster channel or on virtual channels and calculated with the formula for computation of the NDVI. The initial information about the fields was used in official electronic resources, for example, the cadastral map of one part of the Stavropol Territory. Aerial photographs of the territory with a topographic interpretation were taken to assess and refine the pasture contours. Selection of local areas of oppressed vegetation on the pasture under the influence of various negative factors and classification of leaf lesions were based on the assessment of the NDVI field change diagram for the period of time from February to November of the current year by detecting and analyzing the NDVI map and the map of the visible frequency range.In order to research the effectiveness of using the pastures during the production season, the development indicators of 4-month young sheep of the Manych Merino breed were researched. In case of decreasing the level of plant biomass on the pasture, when the indicators of the vegetative index were equal to $0.20 \ldots 0.40$, the level of average daily live weight growth of the young animals under control decreased to $0.099 \pm 0.03(\mathrm{~kg})$.
\end{abstract}

Keywords: vegetation index, remote monitoring, remote sensing, pasture, grazing, sheep.

\section{Introduction}

In modern agricultural production the use of remote sensing techniques (Earth remote sensing) using aerospace services is becoming common. Precision farming technologies, innovative Internet servers for agricultural enterprises, systems of rolling stock monitoring and accounting of expandable items are among the main trends. The monitoring system for various aboveground objects, including pastures and herds, using aircraft, aerostat facilities, satellites and satellite systems is called the aerospace monitoring method, which is divided into four main categories [1-3]. They vary in the technological equipment and the purpose of the results.

So, remote monitoring is a combination of aviation and space monitoring. This concept can include monitoring the environment using instruments installed in remote places of the Earth, for example, in the mountains or the Far North. Their records are transmitted to observation centers using the methods of long-distance information transmission (radio, wire, etc.). Aviation monitoring is carried out from airplanes, helicopters and other aircraft (including balloons, quadrocopters and unmanned aerial vehicles, etc.) that do not rise to space altitudes. Space or satellite monitoring is carried out using space surveillance equipment, for example, from satellites or probes. Integrated aerospace monitoring, sometimes referred to as cartographic and aerospace, is the operational monitoring and control of the state of the environment and its individual components as a result of remote sensing and mapping [4;5].

Aerospace monitoring has multi-scale and multi-temporal advantages. The multiscale feature is determined by the fact that it is possible to survey the surface of the Earth with different resolution and different technological levels simultaneously or quasi-synchronously. This allows making thematic mapping (identification and selection) and generalization of all extensive units of ecosystems (from global to local). The multi-temporal feature of aerospace monitoring ensures the reception of complete and compared information obtained at different periods of time. It is an objective criterion for identifying spatial and temporal changes in ecosystems (daily, seasonal, etc.) [6].

Agricultural exploration of the territory is one of the most effective ways to use space information. The range of issues that can be resolved by satellite imagery includes the tasks of quickly obtaining information on the composition and condition of crops, potential yields, diseases and 
damage to crops by pests and the problem of land resources inventory, biomass assessment, studying the dynamics of agricultural land use [7]. The advantages of distance materials are uniformity and comparability over large areas, great visibility, modernity and permanence. They are crucial for the tasks which are mentioned above.

In our studies remote aerospace monitoring methods were used to isolate local areas of oppressed vegetation on pasture plots based on the use of the vegetation index assessment during the calendar period February-November. The results were used in correction of the production plans for the use of pasture areas for growing agricultural animals.

\section{Materials and methods}

Assessment and clarification of the contours of pasture plots of fields and cultivated areas, the allocation of local areas of oppressed vegetation on cultivated pasture under the influence of various adverse factors, the allocation of weed vegetation focuses were carried out with using remote aerospace monitoring methods.

Evaluation and refinement of field contours was carried out with using remote sensing data (panchromatic, color and multispectral images of the earth's surface). The complex of automated decoding and vectorization was used. After processing, the raster orthomosaic was transformed into a set of vector linear objects, known as field contours. In addition to topographic interpretation, multispectral classification was performed; the NDVI was calculated on the pasture areas [8-10].

Original information of the fields is presented in electronic resources [11;12].

The public cadastral map of the field with the cadastral number 26:01:130301:8 in the Stavropol Territory is presented in Figure 1.

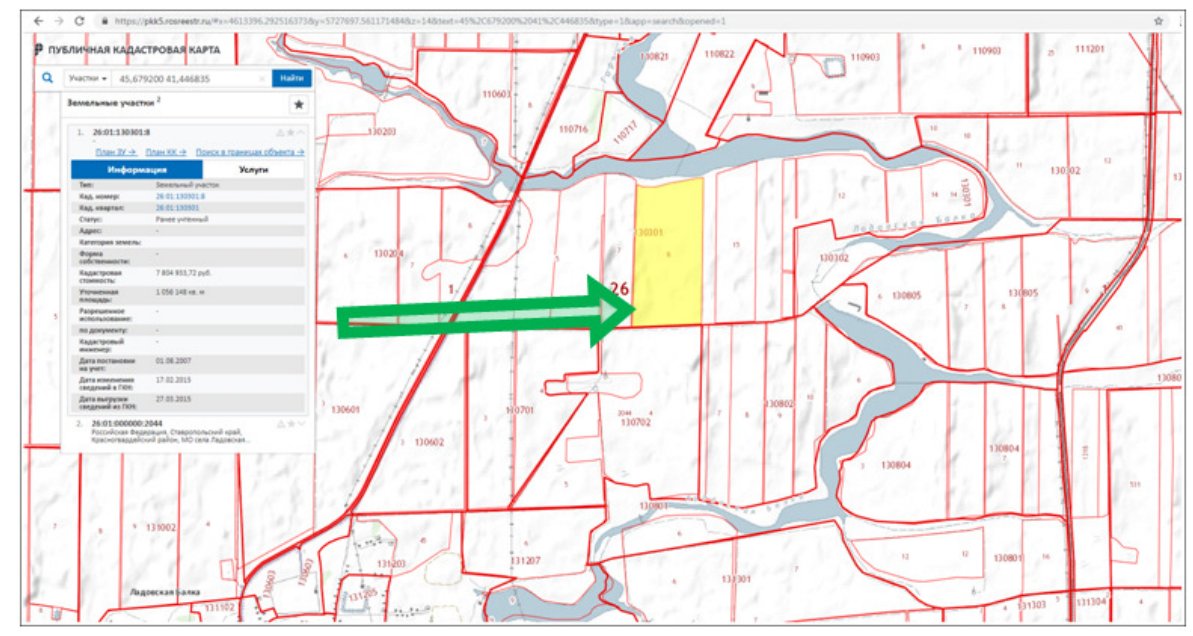

Fig. 1. Public cadastral map of field with cadastral number 26:01:130301:8 in Stavropol Territory

To study the effectiveness of pasture use during the production season, we studied the development indicators of 4-month-old young sheep of the Manych Merino breed. The controlled livestock amounted to 20 heads. Young animals were weighed at the beginning of the accounting months. Gross and average daily weight growth was calculated [13;14].

\section{Results and discussion}

The original contour of the field with the cadastral number 26:01:130301:8 is presented in Figure 2 .

To assess and clarify the contour, aerial photographs of the territory with topographic interpretation were made [12]. The orthomosaic, developed according to the results of aerial photography of the pasture plot is presented in Figure 3.

Evaluation results of the field contours with the cadastral number 26:01:130301:8 are presented in Figures 4, 5 (with blue color marked the original contour, with red one-measured) and in Table1. 


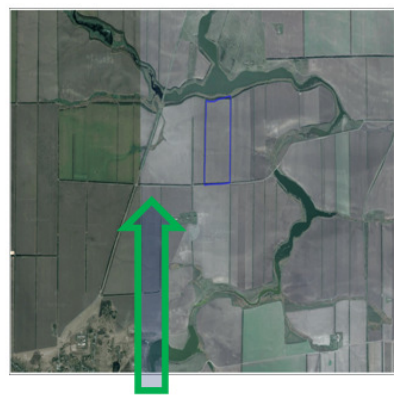

Fig. 2. Original contour of field with cadastral number 26:01:130301:8 (marked with blue color)

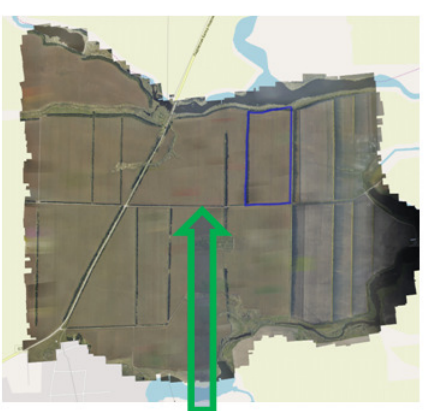

Fig. 3. Orthomosaic, developedaccording to results of aerial photography

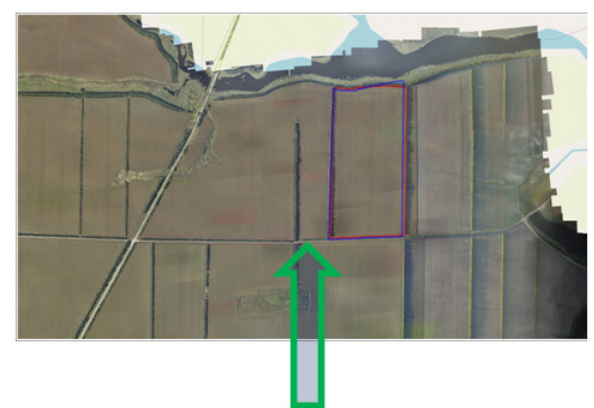

Fig.4. Results of estimation of field contour with cadastral number 26:01:130301:8

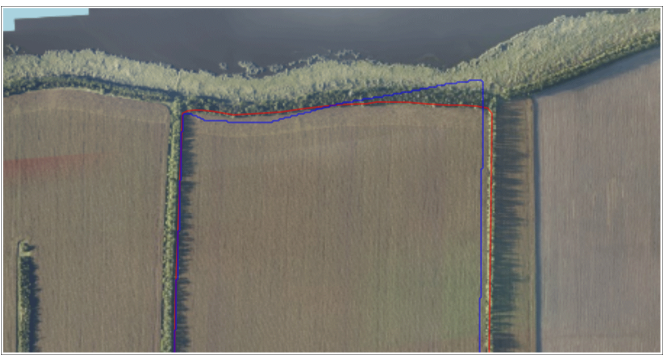

Fig. 5. Evaluation results of field contours with cadastral number 26:01:130301:8

Table 1

Evaluation results of field contours with cadastral number 26:01:130301:8

\begin{tabular}{|c|c|c|c|}
\hline \multirow{2}{*}{$\begin{array}{c}\text { Characteristics of the } \\
\text { measured area }\end{array}$} & \multicolumn{3}{|c|}{ Indicators of measurement } \\
\cline { 2 - 4 } & $\begin{array}{c}\text { According to the } \\
\text { electronic resource }\end{array}$ & $\begin{array}{c}\text { According to the } \\
\text { measurement }\end{array}$ & Difference, \pm \\
\hline Perimeter, $m$ & 4505 & 4359 & -146 \\
\hline Area, $m^{2}$ & 1056148 & 1060615 & +467 \\
\hline
\end{tabular}

The results of refining the size of the pasture showed that the size of the territory obtained by aerial photography differs by $3.24 \%$ along the perimeter. As for the area, it differs by $4.23 \%$ of the territory size obtained by using satellite services to form the information base of the Federal Registration Service [11;12].

Selection of weed vegetation focuses on the cultivated pasture is carried out by visualizing a vegetation index map with a practical survey of pasture plots. It was elicited that, if the NDVI map reflects a healthy green area surrounded by shreds of yellow color, it means this area contains healthy cultivated plants surrounded by less healthy cultivated plants in the pasture plot with homogeneous feeding biomass. Therefore, using a map obtained in the visible range with an unmodified camera, a specialist can find there rapidly growing weeds, which in this case were represented by plants of families:

- Asteraceae (Achilleamillefilium, Tanacetumvulgare, Ambrosia, Xanthium californicum Greene, Centaureacyanus, Centaureaorientalis, Tripleurospermuminodorum, Cirsiumincanum, Sonchusarvensis, Arctiumlappa, Cichoriumintybus, Artemisia absinthium, Artemisia austriaca, Inula, Lactuca, Cyclachaenaxanthiifolia);

- Lamiaceae (Marrubium, Lamium album, Thymus marschallianusWilld, Stachys recta, Salvia verticillata, Salvia nemorosa, Phlomispungens);

- Crucifers (Brassicaceae) (Cardariadraba, Sinapisarvensis, Euclidiumsyriacum, Sisymbrium, Thlaspiarvense, Rorippaaustriaca, Ballotanigra);

- Leguminosae (Glycyrrhizaglabra, Coronillavaria, Viciaeracca, Lotus corniculatus, trifoliumarvense, Trifoliumrepens, Lathyrustuberosus); 
- Gramineae (Hordeumleporinum, Elytrigiarepens, Bromusinermis, Dactylisglomerata, Phragmitesausralis, Loliumperenne, Festuca pratensis);

- Apiaceae (Conium maculatum, Anthriscussylvestris, Japanese Cnidium);

- Polygonaceae (Polygonumaviculare, Rumexconfertus);

- Boraginaceae (Echiumvulgare, Cerinthe minor);

- Chenopodiaceae (Chenopodiumalbum, Atriplextatarica, Kochia);

- Ranunculaceae (Thalictrum, Renunculusacris, Anemone ranunculoides);

- Scrophulariaceae (Verbascumorientale, Melampyrum).

Broadleaf weeds show a high index (the NDVI). It is necessary to analyze the NDVI map (Figure 6) and the map of the visible frequency range (Figure 7) [4;15].

In our researches it was found that the ratio of cereal and leguminous plants in the spring months (March-April) was 3:1, while using the pastures, in summer (July-August) the amount of cereals is higher and the ratio became $4: 1$.

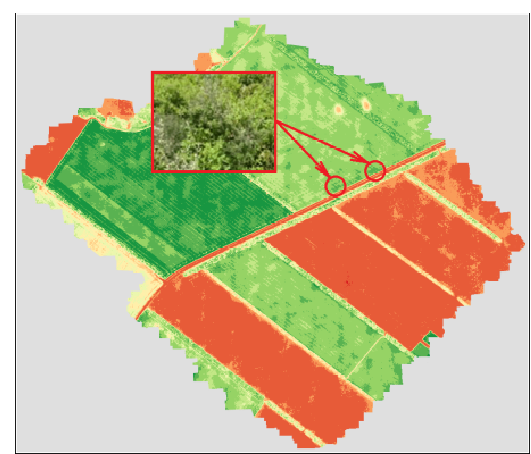

Fig. 6. NDVI map of pasture plots

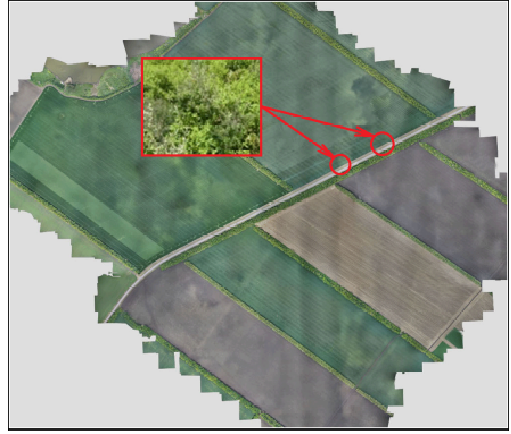

Fig. 7. Map of visible frequency range of pasture plots

On the NDVI map of the field, areas of oppressed vegetation are clearly visible on the cultivated pasture under the influence of various adverse factors, focuses of leaf lesions (Figures 8 and 9).

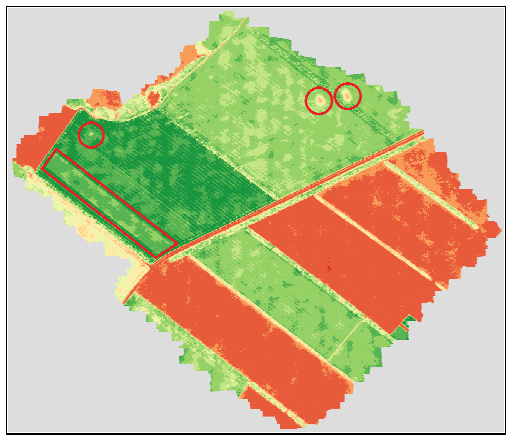

Fig. 8. Marked areas of oppressed vegetation and focuses of leaf lesions on NDVI map

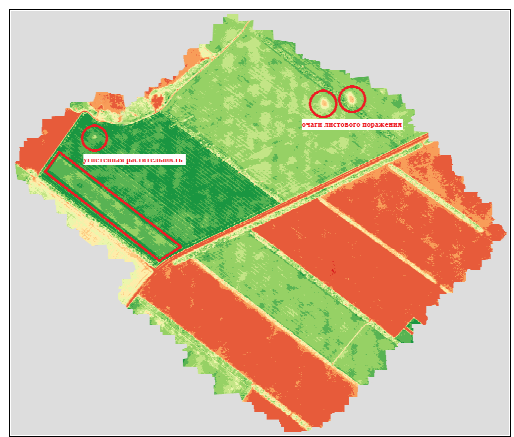

Fig. 9. Recognized areas of oppressed vegetation and leaf lesions on NDVI map

To highlight the contours of the fields, shooting is made in a visible range of RGB by an ordinary camera. The results of the shooting are combined into a visible surface. Further, on this surface they use the mechanisms of machine vision and mark out the contours of the fields. To isolate the oppressed vegetation on the cultivated pasture and leaf damage, a multispectral camera is used, followed by the construction of the NDVI surface. Areas with the lowest NDVI value show depressed vegetation and plants with leaf damage.To isolate focuses of weeds, it is necessary to take pictures in the visible RGB range by a multispectral camera, to build two surfaces: the NDVI surface and the surface in a visible range. Areas of weeds will have a high NDVI. Using this feature on the NDVI surface and pattern recognition on the visible surface, we make the combination of this information. So, the zones with the coincidence of these two conditions will show us the focuses of weed vegetation (Fig. 10). 

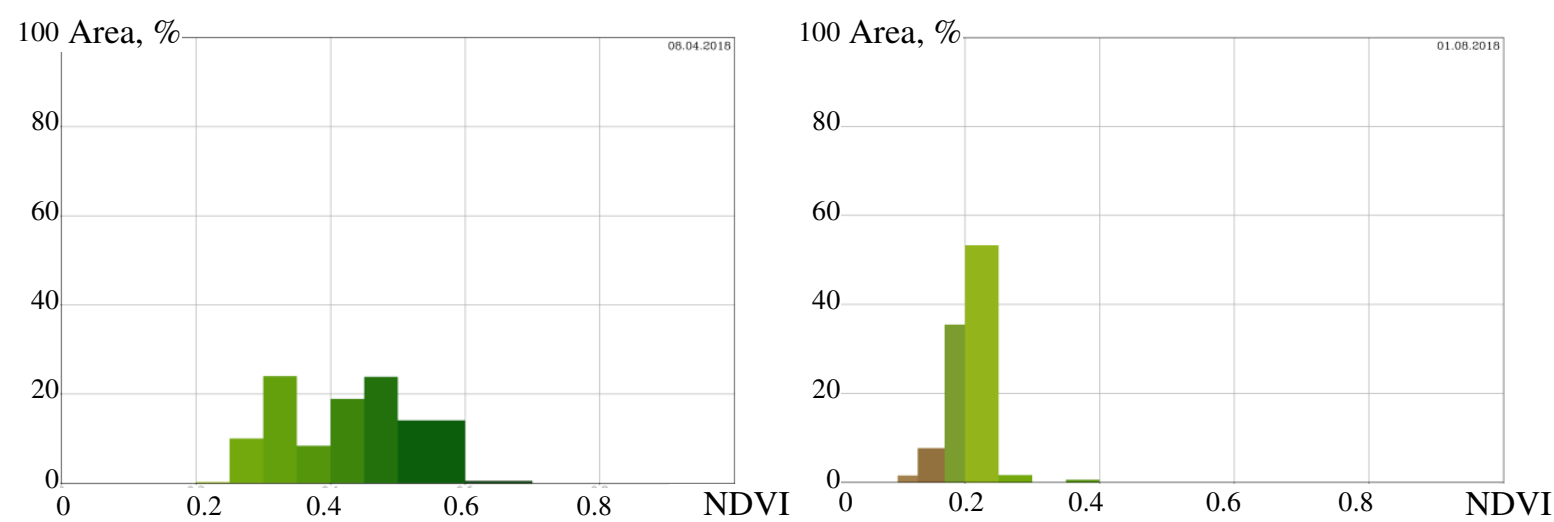

Fig.10. Dynamics of NDVI index during pasture season

The measurements were carried out on April 8 and August 1.

The perimeter of the pasture area was $3597.9 \mathrm{~m}(3.6 \mathrm{~km})$, the pasture area was $803309.1 \mathrm{~m}^{2}$ or 80.3 ha (Table 2).

Table 2

Dynamics of the NDVI index during the pasture season

\begin{tabular}{|c|c|c|c|c|}
\hline \multirow{2}{*}{$\begin{array}{c}\text { Numbers of } \\
\text { NDVI }\end{array}$} & $\begin{array}{c}\text { Results of measurementf rom 8 April } \\
\text { \% of total area of } \\
\text { pasture plot }\end{array}$ & Results of measurement from 1 August \\
\hline $0.20 \ldots 0.25$ & 0.248 & 1992.2 & $\begin{array}{c}\text { \% of total area of } \\
\text { pasture plot }\end{array}$ & area, $\mathrm{m}^{2}$ \\
\hline $0.25 \ldots 0.30$ & 10.04 & 80668.3 & 53.24 & 427.4 \\
\hline $0.30 \ldots 0.35$ & 24.04 & 193107.5 & 1.62 & 12997.5 \\
\hline $0.35 \ldots 0.40$ & 8.38 & 67301.2 & 0.00 & 0.00 \\
\hline $0.40 \ldots 0.45$ & 18.89 & 151704.9 & 0.55 & 4426.2 \\
\hline $0.45 \ldots 0.50$ & 23.84 & 191516.9 & 0.00 & 0.00 \\
\hline $0.50 \ldots 0.60$ & 14.07 & 113049.7 & 0.00 & 0.00 \\
\hline $0.60 \ldots 0.65$ & 0.49 & 3968.3 & 0.00 & 0.00 \\
\hline
\end{tabular}

The results of the assessment of the NDVI index during the pasture season show that in the spring month, $89.22 \%$ (the largest share) was occupied by the plots with the value of the vegetative index 0.3 ... 0.6. In the specified period fattening young sheep of Manych Merino breed were located on the pasture. The grazing pressure of sheep was up to 10 animals per 1 hectare of pastures. Under the conditions of the dry summer season in the Stavropol Territory of the Russian Federation in August the pastures practically burn out, since the annual rainfall is between $350-400 \mathrm{~mm}$, the sum of active temperature ranges from $3200^{\circ}$ to $3500^{\circ}$. This fact makes it difficult to maintain grazing.

Studying the efficiency of growing young sheep has shown that the average live weight of young 4-month-old young sheep was $22.4 \pm 0.35(\mathrm{~kg})$, the average daily weight gain, while growing on a pasture land with NDVI index values, was $0.182 \pm 0.008(\mathrm{~kg})$. With a decrease in the level of plant biomass on pasture with indicators of the vegetative index to indicators of $0.20 \ldots 0.40$, the level of average daily gains of live weight of young animals under control decreased to $0.099 \pm 0.03(\mathrm{~kg})$, and in the subsequent periods of the pasture season top dressing with rough feed was added into the animals rations.

\section{Conclusions}

The use of aerial photography allows specifying the contours of pasture plots, previously obtained using satellite services. The use of remote monitoring allows to select pasture local areas with depressed vegetation. At the same time, it is necessary to conduct additional studies to clarify the identification of weeds and poisonous plants, possibly using more advanced capabilities of multispectral cameras for aerial photography.

The use of the satellite service allows assessing the dynamics of pasture fertility based on the use of the NDVI. A regular decrease of average daily gains of the live weight of the young sheep of the 
Dzhalginskiy Merino breed by 1.84 times in the pasture plots with a decrease in the vegetation index from $0.3 \ldots 0.6$ to the level of $0.2 \ldots 0.4$ is established.

It is promising to study the characteristics of remote monitoring of pasture fertility using multispectral systems.

\section{Acknowledgements}

The work was carried out with the financial support of the Ministry of Science and Higher Education of Russia under Agreement No. 14.613.21.0081 with the Ministry of Ministry of Science and Higher Education of Russia dated November 22, 2017. Uniqueidentifierofworks: RFMEFI61317X0081.

\section{References}

[1] Бедарева О.М. Использование крупномасштабной аэрофотосъёмки для определения некоторых таксационных показателей пустынно-пастбищной растительности (Bedareva O.M. The use of large-scale aerial photography to determine some taxation indicators of desertpasture vegetation). Agrarian science - to agriculture: a collection of articles of the international scientific-practical conference. Barnaul: ASAU, 2006b, vol. 3, pp. 355-357. (In Russian).

[2] Боровиков В.А. Применение методов аэрокосмического мониторинга в исследовании сельского хозяйства Чуйской области (Borovikov V.A. Application of aerospace monitoring methods in the study of agriculture in the Chui region). News of universities of Kyrgyzstan, №8, 2015, pp. 25-27. (In Russian).

[3] Брыксин В.М., Евтюшкин А.В., Кочергин Г.А., Рычкова Н.В. Мониторинг зерновых культур на юге Западной Сибири по данным MODIS и ERS-2 (Bryksin V.M., Evtyushkin A.V., Kochergin G.A., Rychkova N.V. Monitoring of grain crops in the south of Western Siberia according to MODIS and ERS-2). Proceedings of the International Scientific Conference "Probing of Earth Covers with Synthetic Aperture Radar and Radiometers". Ulan-Ude, Enkhaluk settlement, June 24-29, 2013, pp. 79-81. (In Russian).

[4] Железова С.В., Ананьев А.А., Вьюнов М.В., Березовский Е.В. Мониторинг посевов озимой пшеницы с применением беспилотной аэрофотосъемки и оптического датчика GreenSeeker RT200 (Zhelezova S.V., Ananiev A.A., Vyunov M.V., Berezovsky E.V. Monitoring of winter wheat sowing with the use of unmanned aerial photography and the GreenSeeker RT200 optical sensor). Bulletin of Orenburg State University, No. 6, 2016, pp. 56-61. (In Russian).

[5] Lugassi R., Zaady E., Chudnovsky A., Dvash L., Goldshleger N. Spectral Slope as an Indicator of Pasture Quality. Remote Sensing, 7(1), 2015, pp. 256-274.

[6] Mikhailenko I.M. Assessment of crop and soil state using satellite remote sensing data. International Journal of Information Technology \& Operations Management, vol. 1, № 5, 2013, pp. 41-52.

[7] Гарбук С.В. Космические системы дистанционного зондирования земли (Garbuk S.V. Space systems for remote sensing of the earth). Moscow: Publishing house AIB, 1997. 296 p. (In Russian).

[8] Абросимов А.В. Перспективы применения данных ДЗ3 из космоса для повышения эффективности сельского хозяйства в России (Abrosimov A.V. Prospects for the use of remote sensing data from space to improve the efficiency of agriculture in Russia). Geomatics, №4, 2009, pp. 46-49. (In Russian).

[9] Кантемиров Ю.И. Возможности спутникового радиолокационного мониторинга для решения задач сельского хозяйства (Kantemirov Yu.I. Possibilities of satellite radar monitoring for solving problems of agriculture). Geomatics, No. 2, 2011, pp. 85-89. (In Russian).

[10]Книжников Ю.Ф. Аэрокосмические методы географических исследований. Тренинг для студентов высших учебных заведений (Knizhnikov Yu.F. Aerospace methods of geographical research. Training for students of high educational institutions). Moscow: Publishing Center “Academy", 2014. 336 p. (In Russian).

[11] Nebiker S., Lack N., Abächerli M., Läderach S. Light-weight multispectral UAV sensors and their capabilities for predicting grain yield and detecting plant diseases. The International 
Archives of the Photogrammetry, Remote Sensing and Spatial In-formation Sciences, Volume XLI-B1, 2016 XXIII ISPRS Congress, 12-19 July 2016, Prague, Czech Republic.

[12] Public cadastral map of the Russian Federation. [online] [04.03.2019]. Available at: https://pkk5.rosreestr.ru/

[13]Красовский Г.Я. Введение в методы космического мониторинга окружающей среды (Krasovsky G.Ya. Introduction to the methods of space monitoring of the environment). Kharkov: Kharkov Aviation Institute, 1999. 206 p. (In Russian).

[14]Росреестр. Федеральная служба государственной регистрации и картографии (Rosreestr. Federal Service of State Registration and Cartography). [online] [04.03.2019]. Available at: https://rosreestr.ru/site/

[15]Толпин В.А., Лупян Е.А., Барталев С.А., Плотников Д.Е., Матвеев А.М. Возможности анализа состояния сельскохозяйственной растительности с использованием спутникового сервиса «ВЕГА» (Tolpin V.A., Lupyan E.A., Bartalev S.A., Plotnikov D.E., Matveev A.M. Opportunities for analyzing the state of agricultural vegetation using the VEGA satellite service). Optics of the Atmosphere and the Ocean, 2014, V. 27, No. 7 (306), pp. 581-586. (In Russian). 